
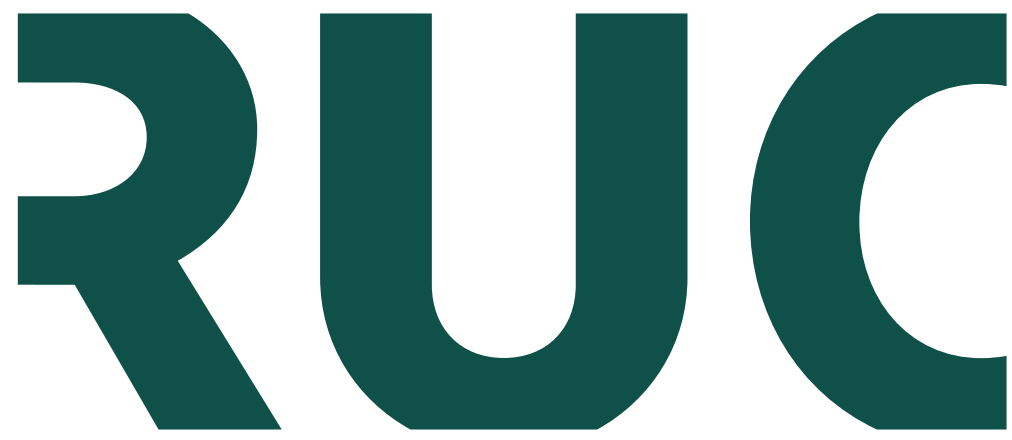

Roskilde University

\title{
Investigation of an Extended Typology for Marketing Destinations with YouTube
}

Sambhanthan, Arunsalam; Thelijjagoda, Samantha; Good, Alice; Scupola, Ada

Published in:

International Journal of Knowledge-Based Organizations

Publication date:

2018

Document Version

Publisher's PDF, also known as Version of record

Citation for published version (APA):

Sambhanthan, A., Thelijjagoda, S., Good, A., \& Scupola, A. (2018). Investigation of an Extended Typology for Marketing Destinations with YouTube. International Journal of Knowledge-Based Organizations, 8(3).

\section{General rights}

Copyright and moral rights for the publications made accessible in the public portal are retained by the authors and/or other copyright owners and it is a condition of accessing publications that users recognise and abide by the legal requirements associated with these rights.

- Users may download and print one copy of any publication from the public portal for the purpose of private study or research.

- You may not further distribute the material or use it for any profit-making activity or commercial gain.

- You may freely distribute the URL identifying the publication in the public portal.

Take down policy

If you believe that this document breaches copyright please contact rucforsk@kb.dk providing details, and we will remove access to the work immediately and investigate your claim. 


\title{
Investigation of an Extended Typology for Marketing Destinations with YouTube
}

\author{
Arunasalam Sambhanthan, Curtin University, Perth, Australia \\ Samantha Thelijjagoda, Sri Lanka Institute of Information Technology, Malabe, Sri Lanka \\ Alice Good, University of Portsmouth, Portsmouth, UK \\ Ada Scupola, Roskilde University, Roskilde, Denmark
}

\begin{abstract}
This article describes how YouTube has been evolving as an e-tool for marketing activities over the past decade. Utilizing YouTube for enhancing marketing endeavours is a strategy practiced by marketing professionals across a growing number of industries. The research documented in this article investigates virtual community-based destination marketing using an extended conceptualisation of a virtual community typology. A non-participant netnographic investigation of virtual communities through a content analysis has been applied in this article to investigate the research questions. The contribution includes the application of an extended typology of virtual communities to YouTube leading to a number of managerial implications for marketing practice on using YouTube as an effective marketing tool.
\end{abstract}

\section{KEYWORDS}

Destination Marketing, Interaction Design, Tourism, Virtual Communities, YouTube

\section{INTRODUCTION}

The percentage of companies using social media for marketing is increasing day by day. Recent advances in social media related research shows a significant increase of social media in marketing different types of products. Research suggests that social media plays an important role in communicating information to customers, but as an antecedent enhancing salesperson behaviours to increase customer satisfaction rather than a direct factor (Agnihotri et al., 2016). Some recent documented studies such as Lohikoski et al. (2016), Sambhanthan and Potdar (2016) deals with virtual communities and parameter based evaluation respectively. YouTube, being a premier social media platform has more than 800 million users visiting each month (YouTube, 2013). Several studies have investigated YouTube from different approaches (Rotman \& Preece, 2010). However, the role of YouTube in tourism related endeavours is still an under investigated area. Studies show that YouTube videos have the potential to substantially affect the experience of tourists (Tussyadiah \& Fesenmaier, 2009). Further, this study show that these videos generate mental pleasure by stimulating the imagination of people as well as impart the feeling of travelling to destinations that the tourists have already visited in the past. To some extent, the above findings show the significance of further research on the use of YouTube platform in destination marketing. Evidently, the use of YouTube as a medium to market tourist destinations remains an open question for exploration in the context of rapidly emerging marketing models using web 2.0. Albeit, Sambhanthan et al. (2016) documented a 
research, which aims to extend the Virtual community typology, propounded by Porter (2005) into another five dimensions namely potential, participation, pattern of use, pollution and power. Hence, this research aims to investigate the following research questions.

1. What is the potential of YouTube in influencing destination marketing efforts of hoteliers?

2. How user perceptions in virtual communities relating to the extended typology could influence destination-marketing efforts of hoteliers?

\section{LITERATURE REVIEW ON VIRTUAL COMMUNITIES}

The theoretical framework of this article relies on the extended typology of virtual communities outlined and published by Sambhanthan and Good (2016). The article discusses of five extended dimensions of the typology of virtual communities propounded by Porter (2004). The key theoretical dimensions and the sub constructs of the extended typology of virtual communities is depicted in Figure 1 in the Appendix.

\section{POTENTIAL}

A key contribution made by Tussyadiah and Fesenmaier (2009) reports that the YouTube videos have the "potential" to substantially affect the experience of tourists. Further, the study states that these videos generate mental pleasure through generating the imagination of people. In addition, the study states that these videos impart the feeling of travelling to the destinations that the tourists have already visited in the past. The potential of these videos to get tourists re-experiencing the past is the most notable effect highlighted throughout this study.

The potential to influence the decision behaviour of users is a meaningful addition to the existing 5 Ps outlined by Porter (2004) which has been used by Sambhanthan et al. (2016) for analysing YouTube content. First, the study strongly argues that the videos are powerful tools for intensifying the interest of potential travellers. Further to this, the study argues that the nature of interactions between the directors and viewers of YouTube videos promote the development of a travel community through which the important experiential information could be effectively shared and exchanged.

While the overall contribution made by Tussyadiah and Fesenmaier (2009) is a sound combination of the experience sharing aspect related research in the tourism domain with a specific focus on technology mediated experience sharing, their research did not include any content towards the creation of dialogue among the users as a way forward to experience sharing through the YouTube platform. In addition, the authors focused more on the role of videos as the mediators of tourist experience. The method utilized in our study focuses on an analysis of videos shared by the tourists in the YouTube platform. Although, the videos are an integral part of virtual community interactions, continuous dialogues among the users' needs follow those, which is more critical in forming purchase related impressions on the minds of travellers.

Another key contribution by Valck et al. (2009) investigated VCs from an entirely marketing perspective. These authors investigated how $\mathrm{VC}$ users engaged themselves as a social and information exchange network and the impact of the social media on users' decision behaviour. The study has key implications for managers, market researchers and marketers based on two main findings: (1) the VCs function as reference groups, which are different from the traditional reference groups; (2) the VC could be utilized to produce a deep understanding about the various aspects of topics discussed, which influence the members. Together, these findings also highlighted the potential of VCs to connect people who would not have met each other during their lifetime if they have not been part of the virtual community. In other words, the VCs have the potential to tie up people who are less likely to meet each other in real-life. However, there should be a threat of anonymity inherently synonym 
with this phenomenon of the virtual communities. The threat of anonymity could cause several issues to the participants with regard to the identity as well as clarity of content published in the forum.

A third contribution by Gretzel et al. (2010) indicates change as a main constraint faced by the destination marketing organizations in facing the future. The authors indicate that the acquisition and utilization of the knowledge on how the issues arises in the past, how it was tackled and how best it can be tackled in the future is the important part of the knowledge which needs to be acquired and preserved. However, this knowledge does include the knowledge about tourist behaviour, how the new technology could be utilized to tackle it as well. From this perspective, this paper could be utilized as a base for forming an understanding of the user behaviour and preserving that knowledge to serve the customer in a better manner in the future. A clear understanding about user behaviour in the YouTube platform along with an effective knowledge management strategy to codify and preserve knowledge about user preferences is a critical concern when it comes to YouTube based destination-marketing initiatives. Hence, the potential of VCs could be utilized as a way forward for tackling all the challenges faced by the destination marketing organizations. Especially, the potential of the VCs in facilitating knowledge exchange through user generated content could be featured as the key potential that has lend towards developing a virtual community based knowledge management approach for the destination marketing organization.

\section{PARTICIPATION}

Virtual brand communities are an integral part of marketing efforts through virtual communities. Casalo et al. (2007) investigated the effect of virtual brand community participation on consumer behaviour. The study explores three main topics. Firstly, the participation of community members in a virtual community and their loyalty to the particular brand with which the community is affiliated. Secondly, the relationship between the community participation and the trust is explored. Thirdly, the effect of trust on consumer loyalty is investigated. The conclusions indicate a threefold interest of these communities for marketers. In fact, the communities could help the marketers to 1) identify the behaviour of the end user, 2) figure out the needs of the user, 3) identification of higher participation as a key for higher loyalty. This clearly demonstrates the importance of participation in virtual community as a success factor in virtual community based marketing. Therefore, the aspect participation needs to be added to the list of typologies identified in the virtual community.

Interest groups are effective tools for virtual marketing activities. Wang et al. (2012) outlined a method for discovering interest groups for marketing in virtual communities. The study proposes an integrated approach through which the marketers could gauge an understanding about the interest groups in virtual communities. The research further investigates on how the social network based frameworks could be utilized to construct a recommendation system. The authors have presented a recommendation system. However, there should be further investigation done with regard to the financial and technical feasibility of implementing the recommender system in a developing country. The first methodological contribution stated by the authors is extending the social network analysis from the offline world to online world. This is a notable contribution to the body of knowledge. Since, the analysis of online communities using the social network analysis techniques could potentially lead towards new insights into the virtual communities' research. The interest groups in turn could be effectively utilized to encourage the participation of members in VCs. The specific interest groups could add value to the destination marketing organizations in the form encouraging user participation in virtual community based discussions on destinations.

\section{PATTERN OF USE}

Tourist information search is a success factor in destination choice. Jacobsen and Muna (2012) investigated the tourist information search and destination choice in a digital age. The study reports 
a very high level of computer and internet usage in tourism related information search by the users. Majority of the tourists used internet based communications not only during their vacation planning activities but also during their stay in the actual destinations. In addition, a tendency of entertaining direct sales through internet has been observed during the course of this study. Thus, the study clearly shows that the pattern of usage has a direct impact on the virtual community based destination marketing efforts. Especially, the users' pattern of internet usage in terms of tourism information search in the digital age clearly demonstrates the impact of the VC based usage pattern on destination marketing. The study further reports that $75 \%$ of the respondents have a Facebook profile. A significant percentage used social media for information search, although it is not essential. The above findings show the pattern of users to use social media in gathering information about destinations to a certain extent.

The study further indicates that the social media presence does not necessarily leads to high level of tourists' turnover for a renowned destination. According to this study, the user approach social media not for the sole purpose of getting information, but for sociability and social rewards in sharing tourism information. It is notable that the motive of sociability is a critical concern, when considering the virtual community based tourism promotion. Moreover, the need for socializing could be effectively tackled through YouTube based virtual communities in building sustainable tourism promotion strategies. In addition to this, the study further states that women find hotel websites as critical and important when comparing with men. The educational level of the participants also proved to be having direct impact on the degree of reliability by tourists on information gathered through Facebook. Particularly, the study indicates that the tourists who have sound educational background are less likely to rely on the information obtained through Facebook. The study further indicates that the young people have more influence from the information gathered through social media when comparing with the elder people. The findings clearly show that there is a significant relationship between the social media usage patterns for tourism information search and the customer background variable such as gender, age and education. However, there are several weaknesses and limitations identified with this particular study. The survey includes some popular sites such as Facebook and some blogs. The limitations of this study include not including the important sites such as YouTube and TripAdvisor. Our investigation is particularly focusing on the pattern of usage by users on utilizing YouTube based community interactions for destination marketing, which needs evidence from studies, which are primarily based on YouTube content. Although, the studies, which are based on other social media sites, could be considered as relevant to this study which cannot make strong recommendations with regard to the usage pattern in YouTube based virtual communities in destination marketing.

\section{POLLUTION}

Pollution in this research is defined as the activity that causes negative effects in the virtual environment. The Hacker's Dictionary (Steele et al., 1983) defines flaming as "speaking rapidly or incessantly on an uninteresting topic or with a patently ridiculous attitude". According to this definition, it could be argued that flaming is a kind of pollution, which take place in the cyberspace through the expression of rabidly, or incessantly on an uninteresting topic. Therefore, the idea of pollution is defined in the course of this research as the flaming activity, which causes negative effects in the virtual environment due to the discussion of rabidly, or incessantly on an uninteresting topic. On the other hand, there are two contradictions involved with the definition of flaming. Firstly, the receiver interprets not all the flames as negative. Secondly, not all the flames, which are interpreted as negative, are intended flames. Therefore, the relative psychology of the sender / receiver plays a major role in determining the degree of negativity involved in YouTube flaming. The above subjectivity involved in the concept of flaming make it quite complex for investigating YouTube based flaming related issues. Another weakness identified with the above study is that the YouTube users who have active usage have had an advantage in filling this survey. In fact, the survey conducted for this study has been circulated 
among active YouTube users and they were asked to promote it amongst their peers. The method used for targeting users was based on the usage. Therefore, passive users had a relative disadvantage in taking part in this survey. Although, there could be an argument saying that it would be interesting to study the opinion of active users than of passive users, the study does not take into account the users who have passive usage due to the fact of flaming. This group is a potentially important and crucial group, which needs to be studied with care. Missing to include this target group is a major weakness of this study. Another major limitation is with the questions asked in the survey took place. The questions asked in this survey are close-ended questions intended to elicit quantitative data. However, a qualitative approach with an explorative nature is essential in this kind of a study in order to record the interpretative nature of the concept flaming. The comments of users in terms of how they interpret the concept of flaming from the YouTube content is essential to be recorded during the course of this research, which is missing in the current methodology adapted for this research.

The effect of flaming on business endeavours is another challenge, which destination marketers face. People write negative or vulgar language / comments on YouTube platform when they do not like the content presented there. This could potentially lead to a negative effect in branding. Moor et al., (2010) reports a study, which investigates flaming related issues on YouTube. The study has been conducted through a survey among YouTube users. Firstly, the study suggests that flaming is a common activity-taking place in the YouTube platform, besides the rejection of this fact by most of the YouTube users. Secondly, the user perceptions on flaming vary among people, but mostly people have a negative perception towards flaming in general. The study also reports that the flaming tends to restrict peoples' tendency to post videos on YouTube. However, the users do not think the flaming issue as a problem themselves. In addition, there were several explanations of flaming were found to be plausible, among which were perceived flaming norms and the reduced awareness of other peoples' feelings. The study also reports flaming as an activity of entertainment, however highlights that flaming is more often focused to express disagreement. There are a number of limitations identified with this study. The definition of flaming is quite confusing. The term flaming means offensive / negative comments, which might not necessarily need to be including all the negative comments made in the YouTube platform. Flaming occurs when both parties (sender and receiver) lost mutual understanding and tends to get into a negative realm of thinking based on the comments made. When considering the case of destination marketing, it is necessary that flaming will not influence peoples' decision with regard to destination consumption as well as their interest to stay in the YouTube platform entertaining further discussions and experience sharing with regard to the specific destinations.

\section{POWER}

The idea of power is defined as the relative control or influencing capacity the virtual community has on its members. The rhetorical meaning of power is yet being researched and the definitions could vary according to the situation. This definition includes the cohesiveness and rigor of virtual communities in influencing its members. Smith et al. (2012) investigated on the differences in the brand related user generated content in YouTube, Facebook and twitter. The study provides three main contributions to the body of knowledge. Firstly, it provides conceptual insights into how different social media sites foster user generated content with different characteristics. Secondly, this research develops some preliminary ideas on how proactive social media marketing relates to user-generated content. Thirdly, this research offers a preliminary set of dimensions for comparing brand related user generated content found on different sites. The study commends on YouTube's ability to self-promote the videos. Koh and Kim (2004) investigated on knowledge sharing in virtual communities from an e-business perspective. The study reports a strong relationship between the level of community knowledge sharing activity and the positive perception of the virtual community members such as community participation and community promotion. However, there are several limitations identified with the above study. 
Mainly, the data for the above research has been collected from a single website based on a single country. Although, the above could be justified as a qualitative case study, the variability of samples is limited in this study. Secondly, there was relatively higher correlation between some variables, which affects the legitimacy of conclusions made on this study. Thirdly, the sample is subjected to bias, since the participation in the sampling is voluntary. Finally, this particular study is exclusively focused on non-profit virtual communities. Seraj (2012) investigated on the intellectual, social and cultural values in online communities. The paper investigates on a value creation perspective of the online communities, which greatly relates to the POWER of the information / experience delivered through the virtual community. However, the research is limited to few samples; therefore, the generalize-ability is limited. Hence, all of the above studies have highlighted the POWER of virtual communities in influencing the choices of users with regard to the product / service preference, trust and loyalty. Therefore, Power should be added to the list of virtual community typologies related to the tourism promotion aspirations of hoteliers.

Social media brand communities are effective in marketing activities online. Laroche et al. (2012) investigated on the effect of social media based brand communities on brand community makers, value creation practices, and brand trust and brand loyalty. The research investigated on whether the social media based brand communities have positive effect on the community elements, value creation practices, brand trust and brand loyalty. The results indicate that there is a positive effect on the community elements by the social media based brand communities. This shows that the social media based virtual communities would have the power to influence the community elements, which includes the participants as well. However, the variables adapted for evaluation in this research is limited to main elements. Xiang and Gretzel (2010) investigated about the role of social media in online travel information search. The study confirms the growing importance of social media in the online tourism domain, with regard to the travel information search. Firstly, the study provides a promising indication about the role of social media in the online travel information domain. Secondly, the study reports that the social media based travel information sources are becoming ubiquitous and first point reference, regardless of the search term used by the traveller. Briefly, the study confirms that social media is becoming as an integral part of online travel sales domain, which cannot be ignored by the travel marketers in the forthcoming years. In other words, social media based virtual communities are becoming inevitable elements of power in the industry.

\section{METHOD}

The experimental objective of this research focuses on gathering user perceptions from selected YouTube based virtual community platforms. The study applies a qualitative netnographic approach using a content analysis method for data collection. The criterial drawn from the extended typology has been depicted in the Table 1 . These criteria were used for collecting data in this research. A nonparticipant netnographic study is justified for this research since the aim is to evaluate the applicability of YouTube based community interactions as a way forward for destination marketing. The study was conducted for five selected YouTube videos containing hundred and thirty-seven (137) user comments which are related to tourism. The specific focus of the YouTube videos was on a tourism destination where the end users recorded their comments regarding the particular destinations. The YouTube comments gathered from the sample videos were transcribed into a word document. The comments were then cleaned and edited for language clarity. A number (up to 137) has been assigned to each comment in order to make it easier for referencing (refer to the Appendix).

\section{RESULTS}

In overall the results indicates that the users' tendency to promote the destinations of their own countries, recall previous travel memories, make comparative assessment among the destinations, 
Table 1. Data collection themes

\begin{tabular}{|c|c|c|}
\hline Typology & Criteria & Rationale \\
\hline \multirow[t]{2}{*}{ Potential } & $\begin{array}{l}\text { Experience } \\
\text { sharing }\end{array}$ & $\begin{array}{c}\text { The potential of YouTube in facilitating the sharing of tourism experience has an effect on marketing activities } \\
\text { conducted based on YouTube }\end{array}$ \\
\hline & Reminiscence & $\begin{array}{c}\text { The potential of YouTube to enable positive reminiscing in the platform is a critical concern in marketing } \\
\text { endeavours }\end{array}$ \\
\hline \multirow[t]{2}{*}{ Participation } & $\begin{array}{l}\text { Interest } \\
\text { Groups }\end{array}$ & $\begin{array}{l}\text { The tendency of users to make interest groups in the Virtual Community platform has a significant effect on } \\
\text { marketing activities }\end{array}$ \\
\hline & Loyalty & $\begin{array}{l}\text { The users' loyalty towards the destinations they enjoyed has to be considered when designing a YouTube based } \\
\text { Virtual Community platform for marketing activities }\end{array}$ \\
\hline \multirow[t]{2}{*}{$\begin{array}{l}\text { Pattern of } \\
\text { Use }\end{array}$} & $\begin{array}{l}\text { Vacation } \\
\text { Planning }\end{array}$ & $\begin{array}{c}\text { Peoples' tendency to plan their vacations while interacting with others in the Virtual Community has an effect on } \\
\text { marketing activities }\end{array}$ \\
\hline & $\begin{array}{l}\text { Information } \\
\text { search }\end{array}$ & The information searching behaviour of users using the virtual community platform is a critical concern \\
\hline Pollution & Flaming & YouTube platform has a tremendous effect on YouTube based marketing activities \\
\hline Power & & The User Generated Content has a power to influence the marketing activities using Social Media. \\
\hline
\end{tabular}

be loyal to the destinations which they enjoyed, plan their vacations during the discussion and seek out travel related information through the virtual community are some of the observable phenomena (Please see Table 2 for the relevant comments for each criterion in the content analysis).

\section{EXPERIENCE SHARING}

Users have a tendency to share their experiences about the destinations when they meet fellow visitors in the virtual community. Both, the positive as well as the negative experiences have an impact on the participants' discussions. The participants discuss their views on the destinations and the reasons they believe the particular destinations are successful. The memories of participants with regard to their visits to the particular destinations are reflected here. This proves that the virtual community interactions are functioning like reminiscent platforms for specific travel memories. The virtual community platforms stimulate the desire to visit the places shown in the videos as depicted in table 3 .

Table 2. Content analysis results overview

\begin{tabular}{|c|c|c|}
\hline Typology & Criteria & User Comment \\
\hline \multirow{2}{*}{ Potential } & Experience sharing & $3,10,16,17,29,42,45,48,60,93$, \\
& & 16,97, \\
& Reminiscence & $107,108,113,116$ \\
\cline { 2 - 3 } & Interest Groups & $106,107,108,113,116,117,131$, \\
& Loyalty & $1,24,29,33$ \\
\cline { 2 - 3 } & Vacation Planning & \\
\hline \multirow{2}{*}{ Pattern of Use } & Information search & $4,12,18,23,88,104$ \\
\hline Pollution & Flaming & \\
\hline Power & & \\
\hline
\end{tabular}




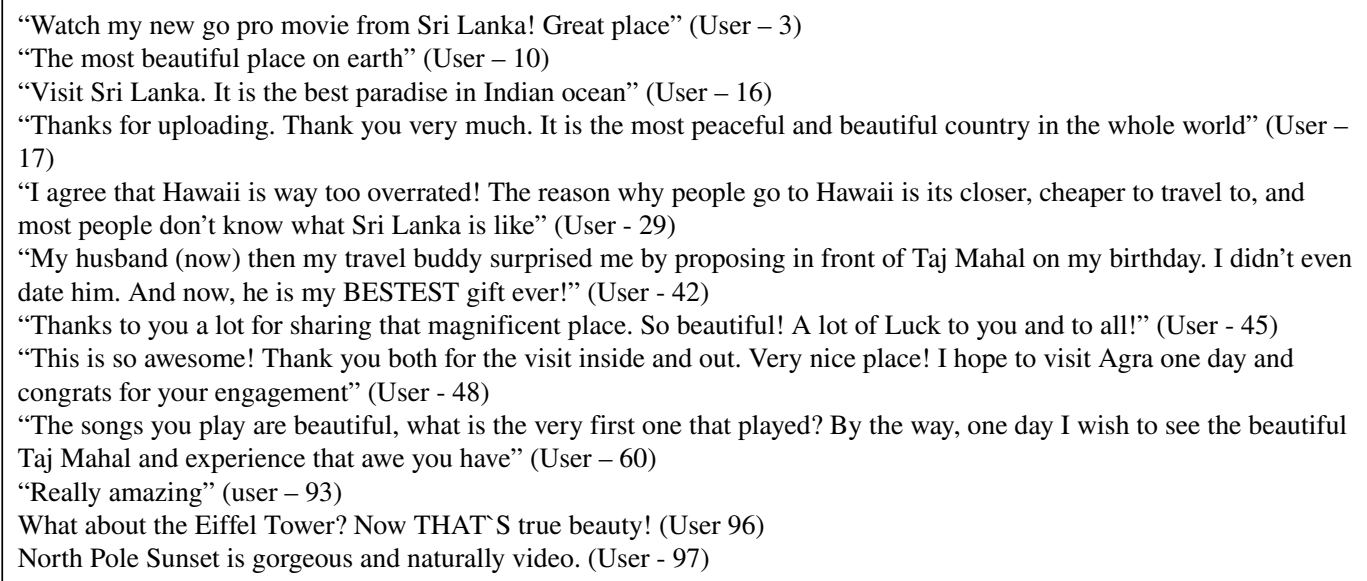

\section{REMINISCENCE}

The user perceptions reflected in the content presented in table 4 shows their reminiscence about the places shown and the memories they have about the particular destinations that have been discussed in the literature.

\section{INTEREST GROUPS}

Users have a tendency to form interest sub-groups in form of discussion circles. The content chain observed throughout the course of this research (see table 5) shows that there are different types of user groups discussing on their particular interests with regard to the destination choice. Particularly, an interest group of New Zealand based destinations has been observed throughout the study. This tendency of forming interest groups could be tackled as an advantage by the marketing professionals when designing their YouTube based destination promotion strategies. Some examples of the interest groups are depicted in the following content abstracted from the YouTube channel.

You must see them! Iceland literally takes your breath away no matter where you are in the country. Everything is just beautiful! No slums or areas to avoid. Even Reykjavik is gorgeous. In New Zealand, a city is a city like anywhere else. The most beautiful part of New Zealand that we saw was Queenstown, which really reminded me of Iceland. (User 107)

I have always wanted to see Iceland and New Zealand! The pictures I see of both of them are just gorgeous! (User - 108) I live just few KM from Bled, Slovenia. I can tell it is really beautiful. Special treasure in my country it is a lot and beautiful forests, wonderful lakes and rivers, nice mountains and very clean water for drink. We are one of very few country were you can drink water from plumbing ... God bless my country. (User - 113)

I have been to New Zealand (gorgeous) and hubby and I are planning a cruise next year to Antarctica. We are winter people and love clean, crisp air, snow, mountains and scenery. I was born in Iceland and next time we go back for a visit we plan to see Greenland! (User - 116) 


\section{LOYALTY}

The above content (Table 5) proves also that the users have a tendency to be loyal to the destinations which they have enjoyed during their visits. The users have shown a loyalty towards the New Zealand destinations which they have admired during their visit to the particular places.

\section{VACATION PLANNING}

The comments show the users' tendency to plan out their vacation visits in the YouTube platform while discussing with the other travelers. Also, the travelers exchange information about destinations in the YouTube platform and assist other people who are planning their vacation in the YouTube platform.

\section{INFORMATION SEARCH}

User comments (Table 6) shows the users' tendency to seek out information regarding the destinations through the YouTube platform. Also, the travelers have a tendency to provide information / comment on the YouTube platform when the fellow travelers are in search of information with regard to their own destination choice.

\section{Table 5. Content related to interest group \& loyalty}

If you go to New Zealand, the South Island is more spectacular. (User - 106)

You must see them! Iceland literally takes your breath away no matter where you are in the country. Everything is just beautiful! No slums or areas to avoid. Even Reykjavik is gorgeous. In New Zealand, a city is a city like anywhere else. The most beautiful part of New Zealand that we saw was Queenstown, which really reminded me of Iceland. (User 107)

I have always wanted to see Iceland and New Zealand! The pictures I see of both of them are just gorgeous! (User - 108) I live just few KM from, Bled, Slovenia. I can tell it is really beautiful. Special treasure in my country it is a lot and beautiful forests, wonderful lakes and rivers, nice mountains and very clean water for drink. We are one of very few countries were you can drink water from plumbing ... God bless my country. (User - 113)

I have been to New Zealand (gorgeous) and hubby and I are planning a cruise next year to Antarctica. We are winter people and love clean, crisp air, snow, mountains and scenery. I was born in Iceland and next time we go back for a visit we plan to see Greenland! Just got back from Vietnam very disappointing... (User 116)

Certainly it is one of the very most beautiful places to be in. But have you been to Greenland or Svalbard or Alaska? Those are other favorites of mine. And Antarctica, but there I haven't been even though they arrange cruises there from my country! (User - 117)

You should include New Zealand's Milford Sound. That country is mind-blowing acid trip of Mother Nature. (User 131)

I have travelled the world and there are many beautiful places around. One I highly recommend you to see is New Zealand's Milford. Sounds it is absolutely breath taking stunning, I've been 3 times to show other people and it's still overwhelming every time, it's a must see. (User - 135)

\section{Table 6. Content related to vacation planning \& information search}

I might go to Sri Lanka next month because I want to go somewhere nice to film. I wanted to go to Spain because I know it will be lovely and sunny and bright for filming, but I will be going on my own and I need wheels to get about, but I don't have a license, but I'm guessing you don't need a license to hire a moped in Sri Lanka. My only fear is whether it will rain a lot in Sri Lanka in June? (User - 1)

I LOVED Sri Lanka. I deeply want to return, but this time on a vacation. The people are fantastic! Hope to see you soon Sri Lanka. (User - 24)

I agree that Hawaii is way too overrated! The reason why people go to Hawaii is its closer, cheaper to travel to, and most people don't know what Sri Lanka is like. (User - 29)

This is the most amazing video of Taj Mahal! I just would like to ask you which video camera have you used? It is as clear as blurry! Please tell me which video camera have you used? Love from India. (User - 33) 


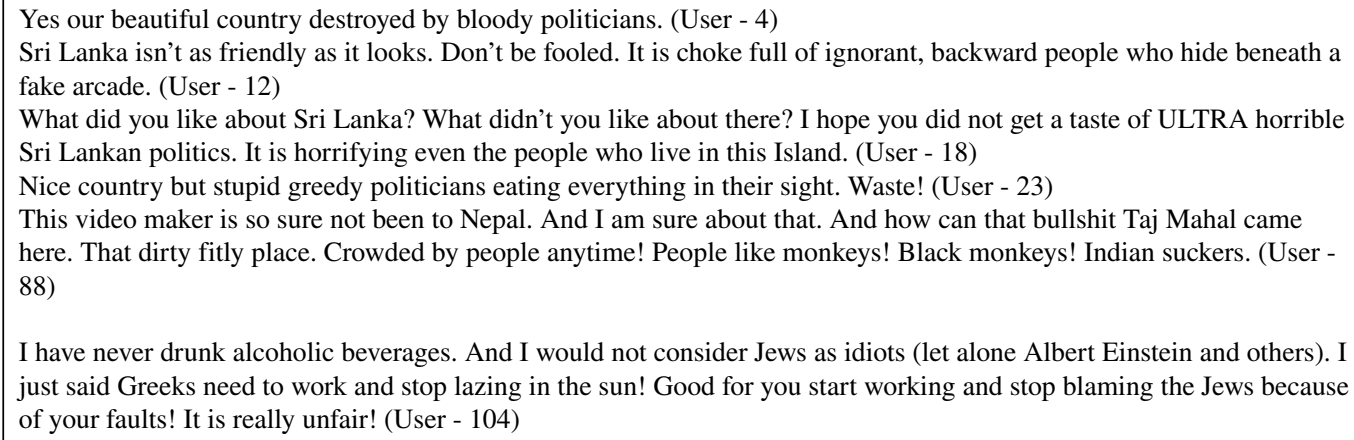

I have never drunk alcoholic beverages. And I would not consider Jews as idiots (let alone Albert Einstein and others). I just said Greeks need to work and stop lazing in the sun! Good for you start working and stop blaming the Jews because of your faults! It is really unfair! (User - 104)

\section{FLAMING}

The analysis shows a considerable amount of flaming happening in the YouTube discussions. People have a tendency to use negative words which could harm the receiver of the communication directly or indirectly. It is not a matter, whether the flaming has been intended or not. But the amount of flaming happening throughout the discussion is a negative factor which could cause issues to the healthiness of the discussions. Table 7 presents the content related to flaming observed in this study.

\section{POWER OF USER GENERATED CONTENT}

The power of user generated content, community knowledge sharing and value creation practices have been featured as the key influential elements on destination marketing. The user comments depict the amount of power the user generated content has on influencing the destination choice of the users. Also, the content further shows that the users have a tendency to share knowledge about the destinations through the virtual community based interactions they have with their peers.

\section{DISCUSSION AND CONCLUSIONS}

Experience sharing and reminiscing are considered two important sub elements of the potential element in the extended typology. Users have a tendency to share their experiences with the destinations when they meet fellow visitors in the virtual community. Both, the positive as well as the negative experiences have an impact on the participants' discussions. The virtual community platforms are observed to be stimulating travel intention as well as functioning as knowledge sharing platforms (Koh \& Kim, 2004). The participants are discussing about their views on the destinations and the reasons they believe for the successfulness of the particular destinations. This proves that the virtual community interactions are functioning like reminiscent platforms for specific travel memories. Online-shared videos can provide mental pleasure to viewers by stimulating fantasies and daydreams, as well as bringing back past travel memories (Tussyadiah \& Fesenmaier, 2009).

Interest groups and customer loyalty / bonding are two main sub elements of the participation element of the extended typology. Users have a tendency to form interest groups within them in the form of discussion circles. An interest group of New Zealand based destinations has been observed throughout the above presented content. This tendency of forming interest groups could be tackled as an advantage by the marketing professionals when designing their YouTube based destination promotion strategies. The users have a tendency to be loyal / bonding to the destinations which they have enjoyed during their visits. This tendency of forming a loyalty towards the destinations could be effectively tackled by the marketers is promoting the destinations using the YouTube platform. In fact, the marketers could form interest groups of loyal customers which could form a basis for 
effective marketing of destinations using the YouTube based community forums. Examples of user formed interest groups and related examples on loyalty / bonding related information according to the published literature shows this is a well-documented phenomenon in the virtual community based marketing (Casalo et al., 2007). Another recent research documents, new method for discovering interest groups for marketing in virtual communities (Wang et al., 2012).

Vacation planning and information search are the other two important sub elements of the usage pattern element of the extended typology. User comments show the users' tendency to plan out their vacation visits in the YouTube platform while discussing with the other travelers. Also, it is noted that the travelers are exchanging information about destinations in the YouTube platform and assisting the other people who are planning out their vacation in the YouTube platform. This could be effectively tackled by the marketers on promoting their destinations to the targeted audience through the YouTube platform. User comments shows that the users' tendency to seek out information regarding the destinations through the YouTube platform. The travelers have a tendency to provide information / comment on the YouTube platform when the fellow travelers are in search of information with regard to their own destination choice. This tendency could be effectively used by the marketers to promote their destinations through gaining a very high opinion through the word of mouth. A recent study reports that $75 \%$ of the users utilized social media platform for vacation planning and many of them uses social media platform for information seeking on tourism related destinations (Jacobsen and Munar, 2012).

Flaming is the main element of pollution in virtual communities. The content shows a considerable amount of flaming happening in the discussions taken place at the YouTube platform with regard to the destinations. People have a tendency to use negative words which could harm the receiver of the communication directly or indirectly. It is not a matter, whether the flaming has been intended or not. But the amount of flaming which is happening throughout the discussion is a negative factor which could cause issues to the healthiness of the discussions taking place in the YouTube platform. Therefore, the pollution of the Virtual community in terms of flaming is a critical factor which influence the successfulness of the virtual community based destination marketing efforts. Flaming is a common activity-taking place in the YouTube platform (Moor et al., 2010).

User generated content depict the power element in the extended typology of virtual communities. The power of user generated content, community knowledge sharing and value creation practices have been featured as the key influential elements on destination marketing. The user comments depict the amount of power the user generated content has on influencing the destination choice of the users. The content further shows that the users have a tendency to share knowledge about the destinations through the virtual community based interactions they have with their peers. Therefore, the power of the virtual communities through the user generated content is identified as a factor that influences the destination marketing efforts of hoteliers. User generated content has a direct effect on user decision making (Sambhanthan and Good, 2012).

Encouraging discussion among users have been found as an effective way to enhance destination marketing as the users had the tendency to share and discuss travel related memories and information in the virtual platform. However, there needs to be some filters applied to this in the platform as irrelevant discussions, inaccurate information and a considerable amount of flaming are also reported in the platform. In contrast, these filters need to comply with the freedom of speech rights of the users. Users' tendency to promote the destinations of their own countries, recall previous travel memories, make comparative assessment among the destinations, be loyal to the destinations which they enjoyed, plan their vacations during the discussion and seek out travel related information through the virtual community are some of the observable phenomena which could be used advantageously by marketers. However, the marketers have to adapt setting specific strategies for addressing these advantageous factors. This implies that the affordability of the business, its size and the nature of tourism products they are offering has a big role to play in shaping their own strategies to use these user tendencies positive towards their marketing efforts. 


\section{REFERENCES}

Agnihotri, R., Dingus, R., Hu, M. Y., \& Krush, M. T. (2016). Social media - influencing customer satisfaction in B2B sales. Industrial Marketing Management, 53(2), 172-180. doi:10.1016/j.indmarman.2015.09.003

Bagozzi, R. P., \& Dholakia, U. M. (2002). Intentional social action in virtual communities. Journal of Interactive Marketing, 16(2), 2-21. doi:10.1002/dir.10006

Casalo, L., Flavian, C., \& Guinaliu, M. (2007). The impact of participation in virtual brand communities on consumer trust and loyalty: The case of free software. Online Information Review, 31(6), 775-792. doi: $10.1108 / 14684520710841766$

Davidson, R. M., Harris, R. W., \& Vogel, D. R. (2008). E-Commerce for community-based tourism in developing countries. Hong Kong: Harris Roger Associates, Star House Konwlon.

Dholakia, U. M., Bagozzi, R. P., \& Klein Pearo, L. (2004). A social influence model of consumer participation in network- and small-group-based virtual communities. International Journal of Research in Marketing, 21(3), 241-263. doi:10.1016/j.jijresmar.2003.12.004

Hennig-Thurau, T., Gwinner, K. P., Walsh, G., \& Gremler, D. D. (2004). Electronic word-of mouth via consumeropinion platforms: What motivates consumers to articulate themselves on the internet? Journal of Interactive Marketing, 18(1), 38-52. doi:10.1002/dir.10073

Jacobsen, J. K. S., \& Munar, A. M. (2012). Tourist information search and destination choice in a digital age. Tourism Management Perspectives, 1(2), 39-47. doi:10.1016/j.tmp.2011.12.005

Koh, J., \& Kim, Y. G. (2004). Knowledge sharing in virtual communities: An e-business Perspective. Expert Systems with Applications, 26(2), 155-166. doi:10.1016/S0957-4174(03)00116-7

Laroche, M., Habibi, M. R., Richard, M. O., \& Sankaranarayanan, R. (2012). The effects of social media based brand communities on brand community makers, value creation practices, brand trust and brand loyalty. Computers in Human Behavior, 28(5), 1755-1767. doi:10.1016/j.chb.2012.04.016

Leimeister, J. M., Sidiras, P., \& Krcmar, H. (2004). Success factors of virtual communities from the perspective of members and operators: an empirical study. In Proceedings of the 37th Hawaii International Conference on System Sciences. doi:10.1109/HICSS.2004.1265459

Lohikoski, P., Kujala, J., Haapasalo, H., Aaltonen, K., \& Ala-Mursula, L. (2016). Impact of trust in communications in global virtual teams. International Journal of Knowledge-Based Organizations, 6(1), 1-19. doi:10.4018/IJKBO.2016010101

Lu, Y., Zhao, L., \& Wang, B. (2010). From virtual community members to C2C e-commerce buyers: Trust in virtual communities and its effect on consumers' purchase intention. Electronic Commerce Research and Applications, 9(4), 346-360. doi:10.1016/j.elerap.2009.07.003

Messinger, P. R., Stroulia, E., \& Lyons, K. (2008). A typology of virtual worlds: Historical Overview and future directions. Journal of Virtual Worlds Research, 1(1), 2-18.

Moor, P. J., Heuvelman, A., \& Verleur, R. (2010). Flaming on YouTube. Computers in Human Behavior, 26(6), 1536-1546. doi:10.1016/j.chb.2010.05.023

Porter, C. E. (2004). A typology of virtual communities: A multi-disciplinary foundation for Future Research. Journal of Computer-Mediated Communication, 10(1).

Rome, C., Pliskin, N., \& Clarke, R. (1997). Virtual communities and society: Towards an integrative three phase model. International Journal of Information Management, 17(4), 261-270. doi:10.1016/S0268-4012(97)00004-2

Rotman, D., \& Preece, J. (2010). The 'We Tube' in the YouTube - creating an online community through video sharing. International Journal of Web Based Communities, 6(3), 317-333. doi:10.1504/IJWBC.2010.033755

Sambhanthan, A., \& Good, A. (2012). Implications for improving accessibility for ecommerce websites in developing countries. International Journal of Knowledge-Based Organizations, 2(2). doi:10.4018/ ijkbo.2012040101 
Sambhanthan, A., \& Good, A. (2016). Virtual communities: Towards an extended typology. Encyclopedia of E-commerce Development, Management and Implementation. Hershey, PA: IGI Global. doi:10.4018/978-14666-9787-4.ch008

Sambhanthan, A., \& Potdar, V. (2016). A study of parameters impacting sustainability in information technology organizations. International Journal of Knowledge-Based Organizations, 7(3), 27-39. doi:10.4018/ IJKBO.2017070103

Sambhanthan, A., Tellijjagoda, S., Good, A., \& Scupola, A. (2016). Virtual community based destination marketing with YouTube: Investigation of a typology. International Journal of Web Portals, 8(1), 32-49. doi:10.4018/IJWP.2016010103

Seraj, M. (2012). We create, we connect, we respect, therefore we are: Intellectual, social and cultural values in online communities. Journal of Interactive Marketing, 26(4), 209-222. doi:10.1016/j.intmar.2012.03.002

Smith, A. N., Fischer, E., \& Yongjian, C. (2012). How brand related user - generated content differs across YouTube, Facebook and Twitter? Journal of Interactive Marketing, 26(2), 102-113. doi:10.1016/j. intmar.2012.01.002

Steele, G., Woods, D., Finkel, R., Crispin, M., Stallman, R., \& Goodfellow, G. (1983). The Hacker's dictionary. New York: Harper and Row.

Szmigin, I., Canning, L., \& Reppel, A. E. (2004). Online community: Enhancing the relationship marketing concept through customer branding. International Journal of Service Industry Management, 16(5), 480-496. doi:10.1108/09564230510625778

Tussyadiah, I. P., \& Fesenmaier, D. R. (2009). Mediating tourist experiences: Access to places via shared videos. Annals of Tourism Research, 36(1), 24-40. doi:10.1016/j.annals.2008.10.001

Valck, K., \& De, . (2009). Virtual communities: A marketing Perspective. Decision Support Systems, 47(3), 185-203. doi:10.1016/j.dss.2009.02.008

Wang, K. Y., Ting, I. H., \& Wu, H. J. (2012). Discovering interest groups for marketing in virtual communities: An integrated approach. Journal of Business Research, 66(9), 1360-1366. doi:10.1016/j.jbusres.2012.02.037

Werthner, H., \& Ricci, F. (2004). E-Commerce and Tourism. Communications of the ACM, 47(12), 101-105. doi:10.1145/1035134.1035141

Wiertz, C., \& De Ruyter, K. (2007). Beyond the call of duty: Why customers contribute to firm hosted commercial online communities. Organization Studies, 28(3), 347-376. doi:10.1177/0170840607076003

Williamson, D. A. (2010, December 8). How Much Will You Spend on Social Media Marketing Next Year? Ad Age Digital. Retrieved March 1, 2010 from http://adage.com/article/digitalnext/social media-marketingspend-year/147544/

Xiang, Z., \& Gretzel, U. (2010). Role of social media in online travel information search. Tourism Management, 31(2), 179-188. doi:10.1016/j.tourman.2009.02.016

YouTube. (n.d.). Statistics. Retrieved 14 February 2013 from http://www.youtube.com/yt/press/statistics.html 


\section{APPENDIX}

Figure 1. Theoretical model

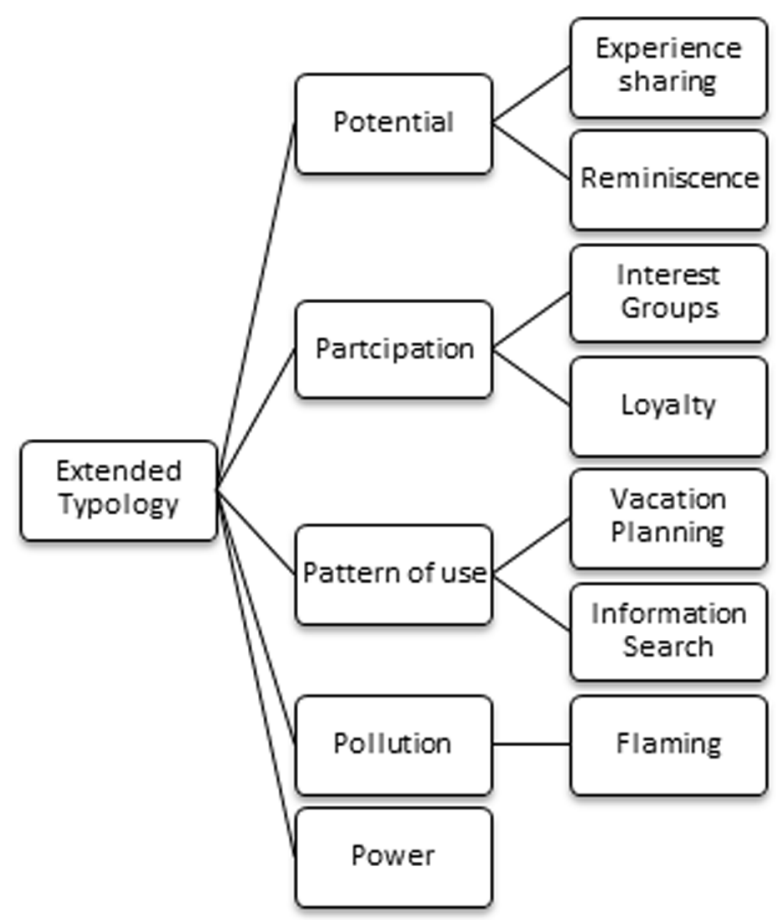

Figure 2. Sample YouTube comment

I michit go sil lanka next month because i wanna go some where nice to film, i wanted to

go sjain because i know it will be lovely and sunny and bright for filming but $i$ will be going on my own and $i$ need wheels to get about but $i$ dont have a licence, but im guessing you dont need a licence to hire a moped in sri lanka.

my only fear is it will rain a lot in sri lanka in june?

Reply * it of

2. slackertours 1 vear and 
Table 8. User comments

\begin{tabular}{|c|c|}
\hline User & Comments \\
\hline 5 & Great Video...! Rain is usually trouble during April, May, October and November. Other than that Sri Lanka is Sunny \\
\hline 6 & $\begin{array}{l}\text { Bikinis were never banned in Sri Lanka! Are you studying law? Then you would know that; what you are playing here is a } \\
\text { hoax. Only mini-skirts were to be banned in Sri Lanka although with the growth of the tourist population this rule was not } \\
\text { imposed! Please check your facts before you comment on a video on your country }\end{array}$ \\
\hline 14 & $\begin{array}{l}\text { I might go to Sri Lanka next month because I want to go somewhere nice to film, I wanted to go to Spain because I know it } \\
\text { will be lovely, sunny and bright for filming but I will be going on my own and I need wheels to get about but I don't have a } \\
\text { license, but I'm guessing you don't need a license to hire a moped in Sri Lanka. My only fear is it will rain a lot in Sri Lanka } \\
\text { in June }\end{array}$ \\
\hline 19 & Nice video!! You guys are amazing and funny!! Greetings from a Sri Lankan \\
\hline 23 & Nice country but stupid greedy politicians eating everything in their sight. Waste \\
\hline 24 & I loved Sri Lanka. I deeply want to return, but this time on a vacation. The people are fantastic. Hope to see you soon Sri Lanka \\
\hline 27 & I'll see you soon mother Sri Lanka \\
\hline 28 & Go Sri Lanka \\
\hline 29 & $\begin{array}{l}\text { I agree that Hawaii is way too overrated!! The reason why people go to Hawaii is its closer, cheaper to travel to, and most } \\
\text { people don't know what Sri Lanka is like }\end{array}$ \\
\hline 30 & $\begin{array}{l}\text { That's just plain snobbery. Give credit when it is due. This is not a competition of who/what/where is the best. It is a short clip } \\
\text { that showcases the beauty of Sri Lanka in } 2 \text { minutes. Learn to appreciate life instead of having the need to make comparisons } \\
\text { all the time. You'll be happier too }\end{array}$ \\
\hline 33 & $\begin{array}{l}\text { This is the most amazing video of Taj Mahal. I just would like to ask you which video camera have you used? It's as clear as } \\
\text { blue ray. Please tell me which video camera have you used? Love from India }\end{array}$ \\
\hline 34 & We used a canon $60 \mathrm{~d}$. Cheers \\
\hline 35 & Excellent photos \\
\hline 36 & Thank You! \\
\hline 37 & Well-put together video! One day I'll have someone to travel the world with! \\
\hline 38 & Good luck:) \\
\hline 39 & This make me want to watch Aladdin \\
\hline 48 & $\begin{array}{l}\text { This is so awesome! Thank you both for the visit inside and out:) very nice place! Hope to visit Agra one day:) and congrats for } \\
\text { your engagement }\end{array}$ \\
\hline 52 & $\begin{array}{l}\text { Doubtful. It was dark and full of people. The center is fenced off so no one could even get close to the marble cenotaphs. } \\
\text { Videos/photos are forbidden, but the inside is not nearly as pretty as the outside anyway }\end{array}$ \\
\hline 71 & All of you are wrong the most beautiful place is Nepal. You can come and visit \\
\hline 73 & The music is so wrong, could be more fun \\
\hline 74 & It's more fun in the Philippines! \\
\hline 75 & The most beautiful place in the earth is Pakistan. That's why America wants Pakistan. \\
\hline 86 & Fantastic photos! Could you please tell me which music is being played in the video? Thanks \\
\hline 90 & Love the music so much \\
\hline 107 & $\begin{array}{l}\text { You must see them! Iceland literally takes your breath away no matter where you are in the country. Everything is just } \\
\text { beautiful! No slums or areas to avoid. Even Reykjavik is gorgeous. In New Zealand - a city is a city like anywhere else. The } \\
\text { most beautiful part of New Zealand that we saw was Queenstown, which really reminded me of Iceland. }\end{array}$ \\
\hline 108 & I have always wanted to see Iceland and New Zealand! The pictures I see of both of them are just gorgeous! \\
\hline 125 & $\begin{array}{l}\text { Almost complete. Yet you forgot to include the most primitive countries yet a cursor to the civilization in the East, such as } \\
\text { Burma, Bagan temples. Nice background music }\end{array}$ \\
\hline
\end{tabular}


Arunasalam Sambhanthan is currently working as a PhD Research Scholar at the School of Information Systems, Curtin Business School at Curtin University, Perth, Western Australia supported by the Curtin Strategic International Research Scholarship. His current research focus is in the area of sustainability in IT organizations. He has a number of publications in peer reviewed journals and conferences. He has four years of industry experience in technical communication.

Samantha Thelijjagoda is a senior lecturer (Higher Grade) in Information Systems Engineering, Sri Lanka Institute of Information Technology, Malabe, Sri Lanka. He is currently serving as the Acting Dean, Faculty of Graduate Studies and Research. He received his first degree in Statistics with first class honors from University of Sri Jayewardenepura, Master of Engineering in Computer Systems Engineering and PhD in Information Systems Engineering from University of Gifu, Japan. His research interests are Computational models of human language processing (NLP), Human language technology (HLT) such as Machine Translations, Information Extraction etc. and Digital linguistics (Corpus Linguistics), which are associated with the area of Computational Linguistics. He is an active member of Computer Society of Sri Lanka and currently the student counsellor of its executive council. $\mathrm{He}$ is the country representative of Technical Committee 8 (TC-8: Information Systems) of International Federation of Information Processing (IFIP). He is also the country in-charge for Skills Certifications of IT professionals in Sri Lanka, which is awarded by Australian Computer Society.

Alice Good is a Senior Lecturer in Human Computer Interaction at the School of Computing, and Course Leader for the Masters of Research (MRes) in Technology at the University of Portsmouth. She gained a PhD in Information Systems from the University of Portsmouth in 2008, and an MSc in Human Centered Computer Systems from the University of Sussex in 2002. Her research predominantly lies in usability and accessibility. She has a particular interest in tools and applications to support wellbeing. This can apply to tools that facilitate cognitive restructuring, behavior modification, self-monitoring, self-soothing and others. In addition, tools that meet the specific needs of people recovering from mental illness. She also provides usability and accessibility consultancy to several small companies as well as advising on mobile apps for wellbeing.

Ada Scupola is an associate professor at the Department of Communication, Business and Information Technologies, Roskilde University, Denmark. Her main research interests include user driven innovation, digital innovation, adoption and diffusion of information and communication technologies (ICT). She has been investigated both the private and the public sector with particular focus on the library sector, facility management service sector and consulting services. She has been visiting scholar in several universities including University of Texas at Austin, University of Michigan, Queensland University of Technology and University of Maryland at College Park. 